\title{
Analysis of Prevalence and Risk Factors of Chronic Rhinosinusitis in Hyperlipidemia Patients
}

\author{
Eun Jung Lee, Ji Hoon Kim, Yun Suk Suh, Byeong Il Choi, Chan Min Jung, and Kyung-Su Kim \\ Department of Otorhinolaryngology, Yonsei University College of Medicine, Seoul, Korea
}

\section{고지혈증 환자에서 만성 비부비동염의 유병률 및 위험인자 분석}

이은정 · 김지훈 · 서연석 · 최병일 · 정찬민 · 김경수

연세대학교 의과대학 이비인후과학교실

Received July 10, 2014

Revised August 6, 2014

Accepted August 11, 2014

Address for correspondence

Kyung-Su Kim, MD, PhD

Department of Otorhinolaryngology,

Gangnam Severance Hospital,

Yonsei University

College of Medicine,

211 Eonju-ro, Gangnam-gu,

Seoul 135-720, Korea

Tel $+82-2-2019-3463$

Fax $+82-2-3463-4750$

E-mail ydrhinol@yuhs.ac
Background and Objectives According to previous studies, acute and chronic cholesterol depletion in the cell membranes of human airway epithelial cells suppresses MUC5AC gene expression. Also statins and lipid-lowering drugs are known to have anti-inflammatory effects. From these results, we hypothesize that the use of statin decreases the prevalence of chronic rhinosinusitis (CRS). Therefore, this study aimed to analyze the correlation between hyperlipidemia and the use of statin and prevalence of CRS in Korea.

Subjects and Method The data were based on the Korean National Health and Nutrition Examination Survey in 2010 and 2011. Symptom-based criteria of European Position Paper on Rhinosinusitis and Nasal Polyps 2012 were used to define CRS. 12000 people were enrolled in this study.

Results The CRS prevalence of hyperlipidemia group (14.13\%) was significantly higher than that of non-hyperlipidemia group $(10.87 \%)(p=0.0005)$. However, the CRS prevalence between statin users (14.27\%) and nonusers (13.94\%) in hyperlipidemia group showed no significant differences. Thus, hyperlipidemia itself was a risk factor of CRS regardless of using statin. Allergic rhinitis was the only significant risk factor of CRS in hyperlipidemia group in multivariate regression analysis.

Conclusion Hyperlipidemia patients who have allergic rhinitis are at risk of CRS regardless of whether they use statins; however, further study using objective data will be required to verify this result. Korean J Otorhinolaryngol-Head Neck Surg 2015;58(1):25-31

\section{서 론}

만성 비부비동염은 최소 12 주 이상 지속되는 비강과 부비동 의 염증으로 정의되는데, 이로 인해 점막의 비후, 섬모수의 감 소 및 기능의 저하, 배상세포 증식 등의 변화가 나타나며 염 증과정이 비가역적이어서 수술적 치료를 요하게 된다. ${ }^{1)}$ 최근 에는 알레르기비염과 만성 비부비동염 및 천식과의 관계에 대해서 많은 연구가 이루어지고 있고 이들 질환 중 하나가 먼 저 발생하였을 때 다른 질환의 유병률이나 동반 가능성이 높고
상부 및 하부 기도 질환들에 대해 unified airway disease로 설명하고 있는 만큼 이들에 대한 역학 및 사회인구학적 위험 인자 분석이 중요하게 대두되고 있다. ${ }^{2-6)}$ 또한 만성 비부비동 염은 나이, 성별, 인종, 거주지, 직업군, 흡연, 사회 경제학적 상 태 및 알레르기 질환의 유무 등 다양한 환경 요인에 의해 발 생하는 다원인성 질환으로 제기되고 있다. ${ }^{7-9)}$ 지금까지 몇몇 제한적인 역학조사가 진행되었으나 전 인구를 기초로 하여 만 성 비부비동염에 대해 진행된 역학적 연구는 부족한 실정이다.

기존 연구에서 사람 호흡기 상피세포에서 세포막 콜레스테 
롤의 급성 결핍이나 만성적인 생성 억제가 MUC5AC 유전자 발현을 억제한다고 보고한 바 있다. ${ }^{10,11}$ 또한 statin 약물은 혈 관내피세포, 대식세포, 수지상 세포 및 T-세포 등을 포함하는 선천적, 후천적 면역 작용에 관여하는 유전자 발현에 다양한 역할을 한다고 알려져 있고, 최근 임상 연구를 바탕으로 한 분 석을 살펴보면 statin 약물치료가 콜레스테롤 수치를 낮출 뿐 만 아니라 전신적인 항염 작용도 하는 것이 증명되었다. ${ }^{12}$ 이러 한 연구결과들로 유추하면, 고지혈증의 치료 목적으로 statin 계통의 약제를 복용하는 경우, 그렇지 않은 경우에 비해 만성 비부비동염 같은 염증성 질환이 적게 발생할 수 있다고 가정 할 수 있다. 이러한 가정하에 본 연구에서는 고지혈증군과 고 지혈증이 없는 정상군으로 구분하여 두 군 간에 만성 비부비동 염의 유병률에 차이가 있는가를 알아보고, 이후 고지혈증군 에서 고지혈증 치료제를 복용하는 치료제 복용군과 복용하 지 않는 치료제 비복용군 간에 만성 비부비동염의 유병률이 차이가 있는가를 알고자 하였다. 또한 고지혈증군에서 만성 비부비동염 발생의 위험인자에 대해서 알아보고자 하였다.

Table 1. Definition of chronic rhinosinusitis: symptom-based diagnostic criteria

Presence of two or more of the following symptoms:

Nasal blockage/obstruction/congestion

Nasal discharge (anterior/posterior nasal drip)

Facial pain/pressure

Reduction or loss of smell

One of which should be blockage or discharge

Duration of symptoms $>12$ weeks

\section{대상 및 방법}

\section{대상 및 조사방법}

2010년 1월부터 2011년 12월까지 시행된 제4기 국민건강영 양조사 결과에서 만 19세 이상의 12000 명을 대상으로 하였다. 조사사업은 조사원에 의한 일반 설문조사와 이비인후과 전공 의에 의한 전문 설문조사로 이루어졌다. 이 중 설문조사에서 고지혈증으로 진단받은 경우가 있는 환자군을 고지혈증군으 로 하였고 그렇지 않은 군을 정상군으로 하였다. 고지혈증군 중 고지혈증 치료제를 복용하는 군을 치료제 복용군으로, 복용하지 않는 군을 치료제 비복용군으로 하였다.

\section{증상기반 진단기준에 따른 만성 비부비동염의 진단}

전문 설문조사는 European Position Paper on Rhinosinusitis and Nasal Polyps(EP3OS) 2012 진단기준을 참조하여 일 반의나 비이비인후과 전문의에 의한 증상기반 진단기준을 기 준으로 작성되었다. ${ }^{13)}$ 이 증상기반 진단기준에 합당한 경우 를 만성 비부비동염으로 정의하였다(Table 1).

\section{위험인자 분석}

이전 만성 비부비동염의 유병률에 대한 연구에서 의미 있 는 연관성을 보였던 위험인자들과 임상적으로 연관성을 의 심할 수 있는 사회인구학적 변수 및 동반 질환들에 대하여 고지혈증군과 만성 비부비동염의 연관성을 보고자 하였다. 분석에 사용된 변수는 16 개이며 항목은 Table 2 와 같다. 연속

Table 2. Definition of factors applied in the analysis

\begin{tabular}{|c|c|}
\hline Variables & Definitions \\
\hline Smoking & $\begin{array}{l}(-) \text { : former smokers or nonsmokers } \\
(+) \text { : current smokers }\end{array}$ \\
\hline Education & $\begin{array}{l}\text { Low: graduated high/middle school } \\
\text { High: graduated university }\end{array}$ \\
\hline Stress & Light or heavy: subjective feelings of stress in daily life \\
\hline Age & Age $<65$ or age $\geq 65$ \\
\hline Sex & Male or female \\
\hline Hyperlipidemia medication & $(-)$ or $(+)$ : history of medication of hyperlipidemia by a doctor \\
\hline Hyperlipidemia duration & Continuous variable \\
\hline Influenza vaccination & $(-)$ or $(+)$ : history of influenza vaccination in the last one year \\
\hline Hypertension & $(-)$ or $(+)$ : history of hypertension diagnosed by a doctor \\
\hline Diabetes mellitus & $(-)$ or $(+)$ : history of diabetes mellitus diagnosed by a doctor \\
\hline Bronchial asthma & $(-)$ or $(+)$ : history of bronchial asthma diagnosed by a doctor \\
\hline Allergic rhinitis & $(-)$ or $(+)$ : history of allergic rhinitis diagnosed by a doctor \\
\hline ARIA classification & Intermittent/persistent, mild/moderate-severe $\rightarrow$ I, II, III, IV \\
\hline Nasal septal deviation & $(-)$ or $(+)$ : nasal septal deviation confirmed by an otolaryngologist during the survey \\
\hline Obesity & $(-)$ or $(+)$ : based on BMI \\
\hline Frequency of alcohol drinking & Low/mid/high frequency: frequency a week (1-3/4/5-6 freq) \\
\hline
\end{tabular}


형 변수인 고지혈증 유병기간을 제외한 모든 변수는 범주형 변 수로 설정되었다. 최근 1년간 인플루엔자 예방접종을 받은 적 있는지 여부에 따라 예방접종 여부를 분류하였다. 또한 고혈 압, 당뇨, 천식, 알레르기비염의 이환 여부는 의사에게 진단받 은 적이 있는지 여부로 결정하였다.

\section{통 계}

고지혈증군과 고지혈증이 없는 정상군, 그리고 고지혈증군 중 고지혈증 치료제 복용군과 치료제 비복용군 간의 만성 비 부비동염 유병률을 구하여 각각 대응된 두 군 간의 유병률의 차이를 보이는가는 chi-square test 분석을 통해 알아보았다. 한편 고지혈증군에서 만성 비부비동염의 위험인자 분석은 단 변량과 다변량 로지스틱 회귀분석을 사용하였다. 단변량 로지 스틱 회귀분석을 통해 각 변수들의 교차비 및 이의 $95 \%$ 신뢰 구간을 산출했으며, 이 중 $p<0.05$ 값을 가지는 변수들에 대 해서 다변량 로지스틱 회귀분석을 실시하여 각 변수들의 보정 된 교차비와 유의성 결과를 통해 고지혈증군에서의 만성 비 부비동염의 위험인자를 다시 한 번 증명하였다. 각 결과의 통 계처리는 복합표본 설계를 감안하였고 프로그램은 SAS version 9.2(SAS Inc., Cary, NC, USA)를 이용하였다. 통계적으 로 유의한 수준은 $p<0.05$ 로 정하였다.

\section{결 과}

\section{고지혈증군과 정상군에서 만성 비부비동염의 유병률}

고지혈증군과 고지혈증이 없는 정상군의 만성 비부비동염 유병률을 각각 구하여 대응된 두 군 간에 유병률이 차이를 보 이는가를 알아보았다. 총 12000 명의 대상 중, 고지혈증 정의 에 합당한 고지혈증군은 1260 명이었고 정상군은 10676 명이 었다. 고지혈증군(1260명)에서 만성 비부비동염으로 진단된 경우는 178명(14.13\%)이었고, 정상군(10676명) 중 만성 비부비

Table 3. Analysis of prevalence of chronic rhinosinusitis according to presence of hyperlipidemia

\begin{tabular}{lrrcc}
\hline \multicolumn{1}{c}{ Variables } & No. & CRS & Prevalence (\%) & p-value \\
\hline $\begin{array}{lrrr}\text { Hyperlipidemia } \\
\text { (-) }\end{array}$ & & & & $<0.05^{*}$ \\
$(+)$ & 10676 & 1161 & 10.87 & \\
\hline * statistically significant. CRS: chronic rhinosinusitis &
\end{tabular}

*statistically significant. CRS: chronic rhinosinusitis

Table 4. Analysis of prevalence of chronic rhinosinusitis in hyperlipidemia group according to use of statin

$\mathrm{n}=1260 \quad$ CRS (-) CRS (+) Prevalence of CRS (\%)

\begin{tabular}{llll}
\hline Statin nonusers (531) & 457 & 74 & 13.94
\end{tabular}

$\begin{array}{llll}\text { Statin users (729) } & 625 & 104 & 14.27\end{array}$

CRS: chronic rhinosinusitis
동염으로 진단된 경우는 1161 명 $(10.87 \%)$ 으로 고지혈증군의 만성 비부비동염 유병률이 유의하게 높은 결과를 보였다 $(p=$ 0.0005)(Table 3).

\section{고지혈증군 중 치료제 복용군과 비복용군에서 만성 비부 비동염의 유병률}

고지혈증군 중 고지혈증 치료제를 복용하는 복용군과 복 용하지 않는 비복용군의 만성 비부비동염 유병률을 각각 구하 여 대응된 두 군 간에 유병률이 차이를 보이는가를 알아보았 다. 고지혈증군(1260명) 중 고지혈증 치료제를 복용하는 복용 군은 729명, 비복용군은 531명이었다. 치료제 복용군에서 만 성 비부비동염의 유병률은 $14.27 \%(104 / 729$ 명), 비복용군에 서 만성 비부비동염의 유병률은 $13.94 \%$ (74/531명)로 두 군 간에 유의한 차이를 보이지 않았다(Table 4). 이러한 결과로 고지혈 증군의 만성 비부비동염 유병률이 정상군보다 유의하게 높으며 이는 치료제 복용 여부와는 무관하다는 것을 알 수 있었다.

\section{고지혈증군에서 만성 비부비동염의 위험인자 분석}

상기 결과로 고지혈증군에서 만성 비부비동염의 유병률이 높은 것을 알 수 있었으므로 고지혈증군에서 만성 비부비동 염의 위험인자가 무엇인지를 알아보았다. 16 개의 가능한 위험 인자에 대한 단변량 로지스틱 회귀분석 결과, 고지혈증군에서 만성 비부비동염의 유의한 위험인자는 알레르기비염 및 allergic rhinitis and its impact on asthma(ARIA) 진단기준상 지 속적/경도와 지속적/중등-고도의 알레르기비염 등이었다(Table 5). 유병률에 대한 다변량 로지스틱 회귀분석 결과 알레 르기비염이 없는 경우에 비해 알레르기비염이 있는 경우에서 4.568의 보정된 오즈비를 나타내어 알레르기비염이 고지혈 증군에서 만성 비부비동염의 유의한 위험인자임을 알 수 있 었다 $(p<0.0001)$ (Table 6). 한편 단변량 회귀분석에서 의의가 있었던 ARIA 진단기준상 지속적/경도와 지속적/중등-고도 알레르기비염에 대해서 알레르기비염과 함께 다변량 회귀분 석을 하지 않았는데 그 이유는 ARIA 진단기준은 알레르기 비염이 있는 환자에 대해서만 정의가 되기 때문에 두 변수를 모두 모형에 넣을 경우 알레르기비염이 없는 환자들의 데이터 가 결측이 되어 알레르기비염의 유의성을 판단할 수 없기 때 문이었다.

\section{고 찰}

고지혈증은 대사증후군의 하나로 그 유병률은 점차 증가하 고 있는 추세이다. ${ }^{14)}$ 지질 이상과 연관된 고지혈증은 흔히 비 정상적으로 증가된 지질을 낮추기 위해 3-hydroxy-3-meth- 
Korean J Otorhinolaryngol-Head Neck Surg I 2015;58(1):25-31

Table 5. The univariate analysis of sociodemographic factors of chronic rhinosinusitis in hyperlipidemia group

\begin{tabular}{|c|c|c|c|c|c|c|}
\hline Variables & No. & CRS & Prevalence $(\%)$ & Crude OR & $95 \% \mathrm{Cl}$ & $p$-value \\
\hline \multicolumn{7}{|l|}{ Medication on hyperlipidemia } \\
\hline$(-)$ & 529 & 74 & 13.99 & 1 & & \\
\hline$(+)$ & 729 & 104 & 14.27 & 0.919 & $0.630-1.338$ & 0.66 \\
\hline Duration of hyperlipidemia & & & & 0.997 & $0.962-1.033$ & 0.87 \\
\hline \multicolumn{7}{|l|}{ Sex } \\
\hline Male & 489 & 71 & 14.52 & 1.112 & $0.738-1.675$ & 0.61 \\
\hline Female & 771 & 107 & 13.88 & 1 & & \\
\hline \multicolumn{7}{|l|}{ Age (years) } \\
\hline$<65$ & 789 & 101 & 12.80 & 1 & & \\
\hline$\geq 65$ & 471 & 77 & 16.35 & 1.227 & $0.832-1.808$ & 0.30 \\
\hline \multicolumn{7}{|l|}{ Education } \\
\hline Low & 1036 & 154 & 14.86 & 1.152 & $0.669-1.982$ & 0.61 \\
\hline High & 223 & 24 & 10.76 & 1 & & \\
\hline \multicolumn{7}{|l|}{ Stress } \\
\hline Low & 904 & 121 & 13.38 & 1 & & \\
\hline High & 352 & 56 & 15.91 & 1.319 & $0.878-1.982$ & 0.18 \\
\hline \multicolumn{7}{|l|}{ Smoking } \\
\hline$(-)$ & 1075 & 152 & 14.14 & 1 & & \\
\hline$(+)$ & 181 & 25 & 13.81 & 1.027 & $0.621-1.696$ & 0.92 \\
\hline \multicolumn{7}{|l|}{ Hypertension } \\
\hline$(-)$ & 513 & 77 & 15.01 & 1 & & \\
\hline$(+)$ & 747 & 101 & 13.52 & 0.910 & $0.616-1.345$ & 0.64 \\
\hline \multicolumn{7}{|l|}{ Diabetes mellitus } \\
\hline$(-)$ & 934 & 128 & 13.70 & 1 & & \\
\hline$(+)$ & 326 & 50 & 15.34 & 1.314 & $0.880-1.961$ & 0.18 \\
\hline \multicolumn{7}{|l|}{ Bronchial asthma } \\
\hline$(-)$ & 1198 & 163 & 13.61 & 1 & & \\
\hline$(+)$ & 62 & 15 & 24.19 & 1.530 & $0.685-3.417$ & 0.30 \\
\hline \multicolumn{7}{|l|}{ Influenza vaccination } \\
\hline$(-)$ & 563 & 70 & 12.43 & 1 & & \\
\hline$(+)$ & 697 & 108 & 15.49 & 1.277 & $0.874-1.866$ & 0.21 \\
\hline \multicolumn{7}{|l|}{ Nasal septal deviation } \\
\hline$(-)$ & 637 & 88 & 13.81 & 1 & & \\
\hline$(+)$ & 621 & 90 & 14.49 & 1.081 & $0.743-1.574$ & 0.68 \\
\hline \multicolumn{7}{|l|}{ Allergic rhinitis } \\
\hline$(-)$ & 1118 & 134 & 11.99 & 1 & & \\
\hline$(+)$ & 135 & 43 & 31.85 & 4.014 & $2.340-6.888$ & $<0.05^{*}$ \\
\hline \multicolumn{7}{|l|}{ ARIA classification } \\
\hline 1) Intermittent/mild & 41 & 10 & 24.39 & 1 & & \\
\hline 2) Intermittent/moderate-severe & 13 & 3 & 23.08 & 1.531 & $0.200-11.732$ & 0.68 \\
\hline 3) Persistent/mild & 12 & 9 & 75.00 & 16.819 & $3.779-74.851$ & $<0.05^{*}$ \\
\hline 4) Persistent/moderate-severe & 20 & 13 & 65.00 & 10.478 & $2.653-41.378$ & $<0.05^{*}$ \\
\hline \multicolumn{7}{|l|}{ Obesity } \\
\hline$(-)$ & 651 & 101 & 15.51 & 1 & & \\
\hline$(+)$ & 606 & 77 & 12.71 & 0.802 & $0.547-1.177$ & 0.26 \\
\hline \multicolumn{7}{|l|}{ Drinking frequency } \\
\hline Low & 567 & 87 & 15.34 & 1 & & \\
\hline Mid & 179 & 18 & 10.06 & 0.569 & $0.311-1.041$ & 0.07 \\
\hline High & 228 & 34 & 14.91 & 0.999 & $0.590-1.691$ & 0.99 \\
\hline
\end{tabular}


ylglutaryl-coenzyme $\mathrm{A}(\mathrm{HMG}-\mathrm{CoA})$ 환원제 억제제인 statin 계열 약물을 기본적으로 사용한다. ${ }^{15)}$ 한편, 최근 statin 계열

Table 6. Multiple logistic regression of selected risk factors of chronic rhinosinusitis in hyperlipidemia group according to allergic rhinitis

\begin{tabular}{|c|c|c|c|}
\hline Variables & $\begin{array}{l}\text { Adjusted } \\
\text { OR }\end{array}$ & $95 \% \mathrm{Cl}$ & $p$-value \\
\hline \multicolumn{4}{|l|}{$\begin{array}{l}\text { Medication on hyperlipidemia } \\
(-)\end{array}$} \\
\hline$(+)$ & 0.946 & $0.628-1.426$ & 0.79 \\
\hline Duration of hyperlipidemia & 1.002 & $0.957-1.048$ & 0.94 \\
\hline \multicolumn{4}{|l|}{ Sex } \\
\hline Male & 1.320 & $0.707-2.465$ & 0.38 \\
\hline Female & 1 & & \\
\hline \multicolumn{4}{|l|}{ Age (years) } \\
\hline$<65$ & 1 & & \\
\hline$\geq 65$ & 0.997 & $0.587-1.692$ & 0.99 \\
\hline \multicolumn{4}{|l|}{ Education } \\
\hline Low & 1.200 & $0.658-2.189$ & 0.55 \\
\hline High & 1 & & \\
\hline \multicolumn{4}{|l|}{ Stress } \\
\hline Low & 1 & & \\
\hline High & 1.202 & $0.741-1.948$ & 0.46 \\
\hline \multicolumn{4}{|l|}{ Smoking } \\
\hline$(-)$ & 1 & & \\
\hline$(+)$ & 1.118 & $0.615-2.032$ & 0.72 \\
\hline \multicolumn{4}{|l|}{ Hypertension } \\
\hline$(-)$ & 1 & & \\
\hline$(+)$ & 0.888 & $0.570-1.383$ & 0.60 \\
\hline \multicolumn{4}{|l|}{ Diabetes mellitus } \\
\hline$(-)$ & 1 & & \\
\hline$(+)$ & 1.518 & $0.926-2.491$ & 0.1 \\
\hline \multicolumn{4}{|l|}{ Bronchial asthma } \\
\hline$(-)$ & 1 & & \\
\hline$(+)$ & 1.355 & $0.482-3.810$ & 0.56 \\
\hline \multicolumn{4}{|l|}{ Influenza vaccination } \\
\hline$(-)$ & 1 & & \\
\hline$(+)$ & 1.299 & $0.815-2.069$ & 0.27 \\
\hline \multicolumn{4}{|l|}{ Nasal septal deviation } \\
\hline$(-)$ & 1 & & \\
\hline$(+)$ & 0.937 & $0.584-1.504$ & 0.79 \\
\hline \multicolumn{4}{|l|}{ Allergic rhinitis } \\
\hline$(-)$ & 1 & & \\
\hline$(+)$ & 4.568 & $2.486-8.395$ & $<0.05^{*}$ \\
\hline \multicolumn{4}{|l|}{ Obesity } \\
\hline$(-)$ & 1 & & \\
\hline$(+)$ & 0.918 & $0.598-1.408$ & 0.69 \\
\hline \multicolumn{4}{|l|}{ Alcohol drinking frequency } \\
\hline Low & 1 & & \\
\hline Mid & 0.554 & $0.293-1.050$ & 0.07 \\
\hline High & 0.910 & $0.468-1.770$ & 0.78 \\
\hline
\end{tabular}

*statistically significant. OR: odds ratio, $95 \% \mathrm{Cl}$ : $95 \%$ confidence interval
약물에서 지질에 대한 작용 이외에도 전신적인 항염증작용 을 한다는 것에 대해 많은 연구가 보고되고 있다. ${ }^{12)}$ 이에 본 연 구를 시작할 때의 가정은 statin 계열 약물의 항염증작용과 MUC5AC 억제작용에 의해 고지혈증 치료제 복용자에서 만 성 비부비동염의 유병률이 낮으리라는 것이었다.

그러나 본 연구결과에 따르면 치료제 복용 유무에 상관없 이 고지혈증 자체가 만성 비부비동염의 유의한 위험인자임을 알 수 있었는데 다음과 같은 이유를 생각해 볼 수 있다. 첫째, 기존 연구에서 살펴보았던 유전자가 하나에 국한되어 있기 때 문에 점소(mucin) 생성 및 염증에 작용하는 다양한 유전자의 영향을 반영할 수 없다는 점이다. 이전 연구에 의하면 인간 기도 상피세포(human airway epithelial cell)에서 methyl-beta-cyclodextrin에 의한 콜레스테롤 억제는 interleukin-1ß 수용체와 mitogen-activated protein kinase 의존 경로를 통하여 이루 어진다고 한다. ${ }^{10)}$ 이러한 기초 연구를 살펴보면 지질을 낮추는 statin 계열 약을 복용할 경우 MUC5AC 유전자 발현이 억제되 어 만성 비부비동염의 발생을 줄일 수 있을 것으로 가정할 수 있지만, 기초 연구는 점소를 바탕으로 하였기 때문에 세포, 조 직, 혈류 및 장기 단계에서 약의 작용을 예측하기에는 어려움 이 있다. 그리고 점소를 생성하는 유전자인 MUC 유전자 중 비 점막에서는 $\mathrm{MUC2}, \mathrm{MUC} 4, \mathrm{MUC5A}$ 가 발현되고, $\mathrm{MUC1}$, MUC2, MUC5A의 mRNA는 배상세포에서 발견되며, 점막하 선에서는 MUC5B가 발현되는 등 점소 생성에 여러 MUC 유 전자가 관여하는 데 반해 기존 연구에서는 MUC5AC만 살펴 보았기 때문에 본 결과가 기초 연구의 가정과 상이한 결과를 보이는 데 영향을 미쳤을 것으로 추측된다. ${ }^{16)}$ 둘째, 환자의 다 양성 및 statin 약제의 다양성을 반영할 수 없다는 점이다. 즉, 환자의 고지혈증 정도가 상이하고, 환자마다 지질을 낮추는 약의 종류, 복용법, 용량 및 투약 기간 등에 차이가 있기 때문 에 이런 차이를 포함한 분석을 위해서는 보다 상세한 문진과 각 약제의 비점막에 대한 작용 연구가 추가로 필요하다고 본 다. 셋째, 만성 비부비동염의 분류에 대한 다양성이다. 만성 비 부비동염은 여러 분류가 가능한데 알레르기성 만성 비부비동 염에서는 호산구가, 비알레르기성 만성 비부비동염에서는 호 중구가 주로 관여하는 것으로 알려져 있다. ${ }^{17)}$ 만성 비부비동 염의 병태생리상 부비동 점막상피는 염증을 일으키는 사이 토카인, 세균, 진균, 호흡성 바이러스 등 다양한 자극에 반응 하여 케모카인을 생성하고 이로 인해 염증의 활성화가 유발 되는데 이때 작용하는 사이토카인이나 케모카인의 종류에 따 라 만성 비부비동염의 종류가 구분되고 임상양상도 다르게 나타나게 된다. 본 연구에서는 만성 비부비동염의 종류를 분 류하지 않고 분석하였기 때문에 위와 같이 statin 복용과 연관 성을 보이지 않았을 수도 있다고 본다. 
국민건강영양조사를 바탕으로 분석한 한국인에서의 만성 비부비동염의 위험인자에 대한 기존 연구결과를 보면 남성, 나이가 많은 경우, 스트레스가 많은 경우, 인플루엔자 백신접 종, 비중격만곡증, 알레르기비염 등이 만성 비부비동염의 유 의한 위험인자로 확인되었다. 또한, 위험인자를 오즈비에 따 라 분석하였을 때에는 ARIA 분류에 따른 지속성/중증 알레 르기비염(ARIA IV)이 가장 중요한 위험인자로 확인되었다. 본 연구결과에 따르면 다변량 회귀분석상 고지혈증군에서 만 성 비부비동염의 유병률에 영향을 미치는 유의한 위험인자 는 알레르기비염이 유일하였다. 만성 비부비동염 발생의 위험 인자로서 알레르기비염의 역할에 대해서는 논란이 많다. 알레 르기비염과 연관성이 있다는 보고에 의하면 비부비동염 환자 에서 알레르기비염의 유병률이 일반인보다 높았고, 비부비동 염으로 재수술을 시행한 환자의 $84 \%$ 가 알레르기비염을 동 반하고 있었다고 한다. ${ }^{18-21)}$ 이와 반대로 만성 비부비동염과 알 레르기비염이 연관성이 없다는 보고도 있다. ${ }^{22)}$ 한편, 고지혈증 군에서 알레르기비염이 만성 비부비동염을 유발하는 기전은 명 확하게 밝혀진 바는 없으나, 고지혈증 환자에 있어 histamine, prostaglandin, leukotriene 등의 염증매개체가 증가하는 경향 을 보인다고 하였는데 알레르기비염의 병인이 가속화되어 만성 비부비동염을 유발할 수 있는 위험인자임일 수 있다고 하였다. 또한, 알레르기비염과 비부비동염이 동반된 환자군에서 비부 비동염만 있는 환자군에 비해 granulocyte macrophage colony-stimulating factor, IL-3, IL-4, IL-5와 CD3+ T세포가 증 가된 소견을 보였다. ${ }^{23)}$ 이처럼 지질 대사에서 중요한 역할을 하 는 사이토카인 매개체에 이상이 발생할 경우 고지혈증을 유발 하게 되는데, 이 역시 고지혈증 환자에서 알레르기비염이 만 성 비부비동염을 유발하는 데 중요한 역할을 한다는 증거가 될 수 있다고 본다.

만성 비부비동염의 위험인자는 진단기준과 대상 및 국가 등 에 따라 차이를 보이며 다양한 인자들이 보고되었다. ${ }^{7)}$ 비중 격만곡증 같은 구조적 위험인자에 의해 섬모운동 장애가 발 생하여 자연공의 기계적 폐쇄가 유발될 가능성이 있고, ${ }^{24)}$ 다른 위험인자로 노화에 따라 섬모기능이 감소하고 섬모 중심 미세 소관의 기능적 결함이 증가함에 따라 환기 및 배출 기능이 감 소하여 부비동의 염증이 지속될 수 있으며, ${ }^{25)}$ 또한 조절되지 않는 당에 의해 염증의 만성화가 지속될 경우에도 만성 부비 동염이 가능하다고 보고되었다. ${ }^{26)}$ 하지만 모든 연구에서 일관 되게 만성 비부비동염의 위험인자로 밝혀진 것은 없으며, 기전 역시 정확하게 밝혀진 바는 없다. 즉, 연구 대상이나 방법, 진단 기준 등에 따라 가능한 위험인자는 다양하므로 여러 연구에 서 밝혀진 가능한 위험인자에 근거하여 만성 비부비동염의 기 전을 연구할 필요가 있다. 본 연구에서는 고지혈증군에서 만성
비부비동염 발생의 유의한 위험인자로 알레르기비염을 확인 할 수 있었다. 하지만 알레르기비염 진단의 일관성, 증상 정도 의 차이, 알레르기비염 원인 항원의 다양성 등에 대한 정보가 부족하고 만성 비부비동염 환자에 있어 비점막에서 염증 세포 의 확인이 어렵기 때문에 이에 대한 추가적인 연구가 더 진행되 어야 할 것이다.

본 연구의 한계점으로 첫째, 만성 비부비동염의 진단기준에 대한 문제이다. 아직까지 국제적으로 확립된 역학조사용 진단 기준이 없으나 EP3OS 2012 진단기준 중 이비인후과 전문의 진단기준에 따르면 증상뿐만 아니라 내시경 혹은 부비강 단 층촬영으로 확인된 소견을 포함하는 것으로 되어 있다. 그러 나 본 연구는 증상기반의 진단이므로 위의 진단기준에 비해 객관성이 결여될 수 있다. 내시경 소견이나 영상의학적 소견이 추가된다면 임상적으로 유용한 자료가 될 수 있겠지만, 대규 모 역학조사에서 영상학적 검사를 선별검사로 시행하기에는 한계가 있고 내시경 검사 역시 현실적인 제약이 있기에 역학 조사를 위해 확립된 만성 비부비동염의 진단 기준을 만드는 것이 중요하겠다. 둘째, 고지혈증의 진단이 지질을 반영하는 객 관적인 혈액 수치가 아닌 설문에 의한 것이므로 이 또한 객관 성이 떨어질 수 있어 수치로 근거한 객관적인 추가 연구가 필 요할 것으로 사료된다. 셋째, 고지혈증군에서 고지혈증 약 종 류에 따른 차이, 복용기간 및 투약 방법의 차이 등이 있기 때 문에 이의 영향도 고려할 인자라 할 것이다. 넷째, 고지혈증군 에서 알레르기비염의 위험인자를 확인함에 있어 그 연관관계 가 불충분하다는 것이다. 다섯째, statin의 전신적인 항염증작 용이 비강과 부비동의 국소적인 항염증작용에 얼마나 효율적 으로 작용하는지에 대한 추가적인 연구가 필요할 것이다.

이상의 결과를 보면, 만성 비부비동염의 유병률은 고지혈증 치료제 사용유무에 상관없이 고지혈증군에서 유의하게 높은 유병률을 보여 고지혈증 자체가 만성 비부비동염의 위험인자 일 가능성을 알 수 있었다. 또한, 고지혈증군에서 만성 비부비 동염의 유의한 위험인자로 알레르기비염이 관련됨을 알 수 있 었다. 차후 이러한 결과를 객관화하기 위한 추가 연구가 필요하 리라 생각한다.

\section{Acknowledgments}

We appreciate Korean Society of Otorhinolaryngology-Head and Neck Surgery in South Korea and members of the Division of Chronic Disease Surveillance in Korea Centers for Disease Control and Prevention for participating in this survey and the dedicated work they provided to this study.

\section{REFERENCES}

1) Benninger MS, Ferguson BJ, Hadley JA, Hamilos DL, Jacobs M, Kennedy DW, et al. Adult chronic rhinosinusitis: definitions, diagnosis, epidemiology, and pathophysiology. Otolaryngol Head Neck Surg 
2003;129(3 Suppl):S1-32.

2) de Benedictis FM, del Giudice MM, Severini S, Bonifazi F. Rhinitis, sinusitis and asthma: one linked airway disease. Paediatr Respir Rev 2001;2(4):358-64.

3) Passalacqua G, Ciprandi G, Canonica GW. The nose-lung interaction in allergic rhinitis and asthma: united airways disease. Curr Opin Allergy Clin Immunol 2001;1(1):7-13.

4) Feng $\mathrm{CH}$, Miller MD, Simon RA. The united allergic airway: connections between allergic rhinitis, asthma, and chronic sinusitis. Am J Rhinol Allergy 2012;26(3):187-90.

5) Bachert C, van Cauwenberge P, Khaltaev N; World Health Organization. Allergic rhinitis and its impact on asthma. In collaboration with the World Health Organization. Executive summary of the workshop report. 7-10 December 1999, Geneva, Switzerland. Allergy 2002;57 (9):841-55.

6) Halpern LR. Allergic rhinitis and the unified airway: a therapeutic dilemma. Oral Maxillofac Surg Clin North Am 2012;24(2):205-17, viii.

7) Kim YS, Kim NH, Seong SY, Kim KR, Lee GB, Kim KS. Prevalence and risk factors of chronic rhinosinusitis in Korea. Am J Rhinol Allergy 2011;25(3):117-21.

8) Hamilos DL. Chronic rhinosinusitis: epidemiology and medical management. J Allergy Clin Immunol 2011;128(4):693-707; quiz 708-9.

9) Min YG, Jung HW, Kim HS, Park SK, Yoo KY. Prevalence and risk factors of chronic sinusitis in Korea: results of a nationwide survey. Eur Arch Otorhinolaryngol 1996;253(7):435-9.

10) Song KJ, Kim NH, Lee GB, Kim JH, Kwon JH, Kim KS. Cholesterol depletion in cell membranes of human airway epithelial cells suppresses MUC5AC gene expression. Yonsei Med J 2013;54(3):679-85.

11) Lee EJ, Song KJ, Kwon JH, Park AY, Jo KH, Kim KS. Chronic cholesterol depletion by lovastatin suppresses MUC5AC gene expression in human airway epithelial cells. Am J Rhinol Allergy 2014;28(3): e125-9.

12) Bu DX, Griffin G, Lichtman AH. Mechanisms for the anti-inflammatory effects of statins. Curr Opin Lipidol 2011;22(3):165-70

13) Fokkens WJ, Lund VJ, Mullol J, Bachert C, Alobid I, Baroody F, et al. EPOS 2012: European position paper on rhinosinusitis and nasal polyps 2012. A summary for otorhinolaryngologists. Rhinology 2012;50(1): $1-12$.

14) Ford ES, Li C, Zhao G. Prevalence and correlates of metabolic syndrome based on a harmonious definition among adults in the US. J Diabetes 2010;2(3):180-93.

15) Gudzune KA, Monroe AK, Sharma R, Ranasinghe PD, Chelladurai Y, Robinson KA. Effectiveness of combination therapy with statin and another lipid-modifying agent compared with intensified statin monotherapy: a systematic review. Ann Intern Med 2014;160(7):46876.

16) Severn TL, Hutton DA, Sama A, Wilson JA, Birchall JP, Pearson JP. Expression of MUC2 and MUC5AC by human nasal mucosa. Biochem Soc Trans 1997;25(1):2S.

17) Rhyoo C. Roles of IL-8 in the pathogenesis of chronic rhinosinusitis. J Rhinol 2006;13(1):5-9.

18) Savolainen S. Allergy in patients with acute maxillary sinusitis. Allergy 1989;44(2):116-22.

19) Karlsson G, Holmberg K. Does allergic rhinitis predispose to sinusitis? Acta Otolaryngol Suppl 1994;515:26-8; discussion 29.

20) Emanuel IA, Shah SB. Chronic rhinosinusitis: allergy and sinus computed tomography relationships. Otolaryngol Head Neck Surg 2000;123(6):687-91.

21) Berrettini S, Carabelli A, Sellari-Franceschini S, Bruschini L, Abruzzese A, Quartieri F, et al. Perennial allergic rhinitis and chronic sinusitis: correlation with rhinologic risk factors. Allergy 1999;54(3):242-8.

22) Hinriksdóttir I, Melén I. Allergic rhinitis and upper respiratory tract infections. Acta Otolaryngol Suppl 1994;515:30-2.

23) Hamilos DL, Leung DY, Wood R, Cunningham L, Bean DK, Yasruel $Z$, et al. Evidence for distinct cytokine expression in allergic versus nonallergic chronic sinusitis. J Allergy Clin Immunol 1995;96(4):53744.

24) Karaman M, Tek A. Deleterious effect of smoking and nasal septal deviation on mucociliary clearance and improvement after septoplasty. Am J Rhinol Allergy 2009;23(1):2-7.

25) Ho JC, Chan KN, Hu WH, Lam WK, Zheng L, Tipoe GL, et al. The effect of aging on nasal mucociliary clearance, beat frequency, and ultrastructure of respiratory cilia. Am J Respir Crit Care Med 2001; 163(4):983-8.

26) Zhang Z, Adappa ND, Lautenbach E, Chiu AG, Doghramji L, Howland $\mathrm{TJ}$, et al. The effect of diabetes mellitus on chronic rhinosinusitis and sinus surgery outcome. Int Forum Allergy Rhinol 2014;4(4):315-20. 